\title{
The Effect Of Problem Based Learning On Undergraduate Oral Communication Competency
}

David S. Mandeville, Merrimack College, USA

Tiffanie K. Ho, California State University, Sacramento, USA

Lindy A. Valdez, California State University, Sacramento, USA

\begin{abstract}
Purpose: The aim of this study was to ascertain the effect of Problem Based Learning (PBL) on student oral communication competency gains.

Methods: Eighty students from two consecutive undergraduate Kinesiology courses (Spring semesters, 2014-15) formed into 29 small groups and were studied. Oral communication competency was assessed using a customized rubric and digital recordings of student presentations. Changes to oral communication competency across time were tested using a dependent $t$-test; $\alpha<.05$.

Results: Significant inter-rater agreement was found at both time points for oral communication rating, and student groups demonstrated significant oral communication gains across time.

Conclusions: Collaborative learning was shown to improve students' oral communication competency. Future study is required to determine the influence of student motivation and goal orientation on oral communication competency, in relation to the various phases of knowledge creation occurring within student groups.
\end{abstract}

Keywords: Collaborative Learning; Problem Based Learning; Oral Communication Competency; Kinesiology Education

\section{INTRODUCTION}

\section{Oral Communication Competency}

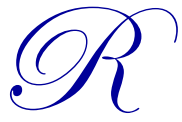

ecently, competency-based educational models have found favor in professional education programs including chemistry, teacher education and medicine due to their emphasis on ability outcomes (Williams \& Handa, 2016; Frank et al., 2010; Albanese et al.,, 2008). The competency-based curricula model shifts the focus from the amount of time a student is immersed in the content area to the development of their ability in the competencies present in their future practice. The concept of competency is seen as an observable ability which changes across time, is embedded into the environment of practice, and spans a spectrum of ability from novice to mastery (Frank et al., 2010). Competence in the allied health care professions has been further described as the relationship between an ability in a person, a task in the clinical world, and the ecology of the health care context (Epstein \& Hundert, 2002).

Oral communication is a necessary ability for allied health care providers as the quality of the patient-clinician relationship affects both the health and recovery of patients. Expert oral communication may improve a patient's understanding of their illness, thereby reducing their anxiety during the shared clinical decision making (Epstein \& Hundert, 2002). In this manner, effective oral communication is thought to positively influence the costs and outcomes of chronic disease management. Therefore, developing oral communication competency in undergraduate Exercise Science education may be a necessary goal as this competency plays an important role in the future clinical settings that students hope to enter. 


\section{Problem Based Learning Theory}

Collaborative learning techniques have been shown to promote professional competencies including: oral communication, abstract problem solving, self-directed learning, managing uncertainty, and teamwork (Epstein \& Hundert, 2002). These dimensions of professional competency are considered integral to a $21^{\text {st }}$ century clinical career where ambiguous problems are solved collaboratively using remote communication. Thus, collaborative learning educational goals are thought to be critical to the effort of preparing aspiring undergraduate clinicians for their future health care careers.

Little research exists to support the use of traditional lecture for the achievement of professional competency. However, the literature supporting the development of professional competency for collaborative learning methods is conclusive (Felder \& Brent, 2004; Prince \& Felder, 2006). Problem Based Learning (PBL) is a collaborative learning method which was designed to develop clinical reasoning (Epstein \& Hundert, 2002) and promote deep learning (Dods, 1997). Students engaged in the PBL method are iteratively brought to a more advanced state of intellectual development while taking agency for their education and learning to question expert opinion (Biggs, 1999; Blumenfeld et al., 2006; Felder \& Brent, 2005; Norman \& Schmidt, 1992; Prince \& Felder, 2006). The value added of PBL is the development of transferable and enduring professional competencies. The professional competencies chosen for development in the current PBL setting included: problem solving, critical thinking, evidence-based practice, and oral communication (Mandeville \& Stoner, 2015).

The development of professional competency for the PBL student is likely the result of the iterative, peer reviewed formative assessments upon which PBL is based (Albanese \& Mitchell, 1993; Gijbels, et al., 2005; Mandeville \& Stoner, 2015; Vernon \& Blake, 1993). Prince and Felder (2006) define learning as occurring when new information has been integrated into one's existing cognitive and personal belief structures. Vygotsky's (1962) social constructivism theory suggests that personal meaning is co-constructed from an experiential event involving dialog and interaction with others (Vygotsky, 1962). Nanoka \& Takeuchi (1996) posited that knowledge creation occurs when tacit knowledge is converted to explicit knowledge, using both written and oral communication. To facilitate this conversion process, the context for interaction among individuals across time is required. The theoretical framework of social constructivism suggests that to have an effective learning experience, peer collaboration must be optimized in the classroom. The collaborative learning environment of PBL is theorized to promote knowledge creation by inducing students to co-construct knowledge within the dialog of small groups in which prior beliefs and misconceptions are modified in light of new information (Prince \& Felder, 2006). In addition, the availability of peer-review within the collaborative PBL model serves as a formative assessment that fosters growth in professional competence by providing low risk feedback to iteratively expand a student's zone of proximal development (Epstein \& Hundert, 2002; Powell \& Kalina, 2009).

\section{Problem}

Although PBL is theorized to promote transferable professional competency gains, there exists limited work that objectively describes the effect of PBL on the development of undergraduate student oral communication competency. Therefore, the purpose of this study was to describe the effect of PBL on oral communication competency gains for undergraduate Exercise Science students. Evidence of oral communication gains by undergraduate students may improve the professional preparation of future allied health care providers.

\section{METHODS}

Eighty students from two consecutive undergraduate Kinesiology courses (Spring semesters, 2014-15) formed into small groups $(n=29)$ and signed voluntary consent for digital recording. These students comprised convenience samples sorted by registration date and thus were representative of upper division students in the Exercise Science Program who had completed the pre-requisite anatomical course work with a C- or better and the required oral communications class as fulfillment of General Education requirements. The Kinesiology courses lasted 15 weeks and included two 50-minute class sessions and a 2.5-hour laboratory session/week. The same professor (D.S.M.), using a student-centered, collaborative learning teaching strategy called Problem Based Learning (PBL), taught students using identical course content and learning goals. The PBL teaching strategy required students to self- 
select into small groups (3-5 students per group) based on shared career goals. In weekly laboratory meetings, each group completed a problem solving sequence (evaluated using a rubric) in order to develop a case report addressing an open-ended, real world human movement problem (Figure 1). During the first 60 minutes of laboratory, the groups' findings were orally presented (12-minute maximum time limit) as PowerPoint presentations in which the group determined the content with minimal professor supervision.

Figure 1. The problem solving cycle iteratively employed by students for their laboratory group presentation.

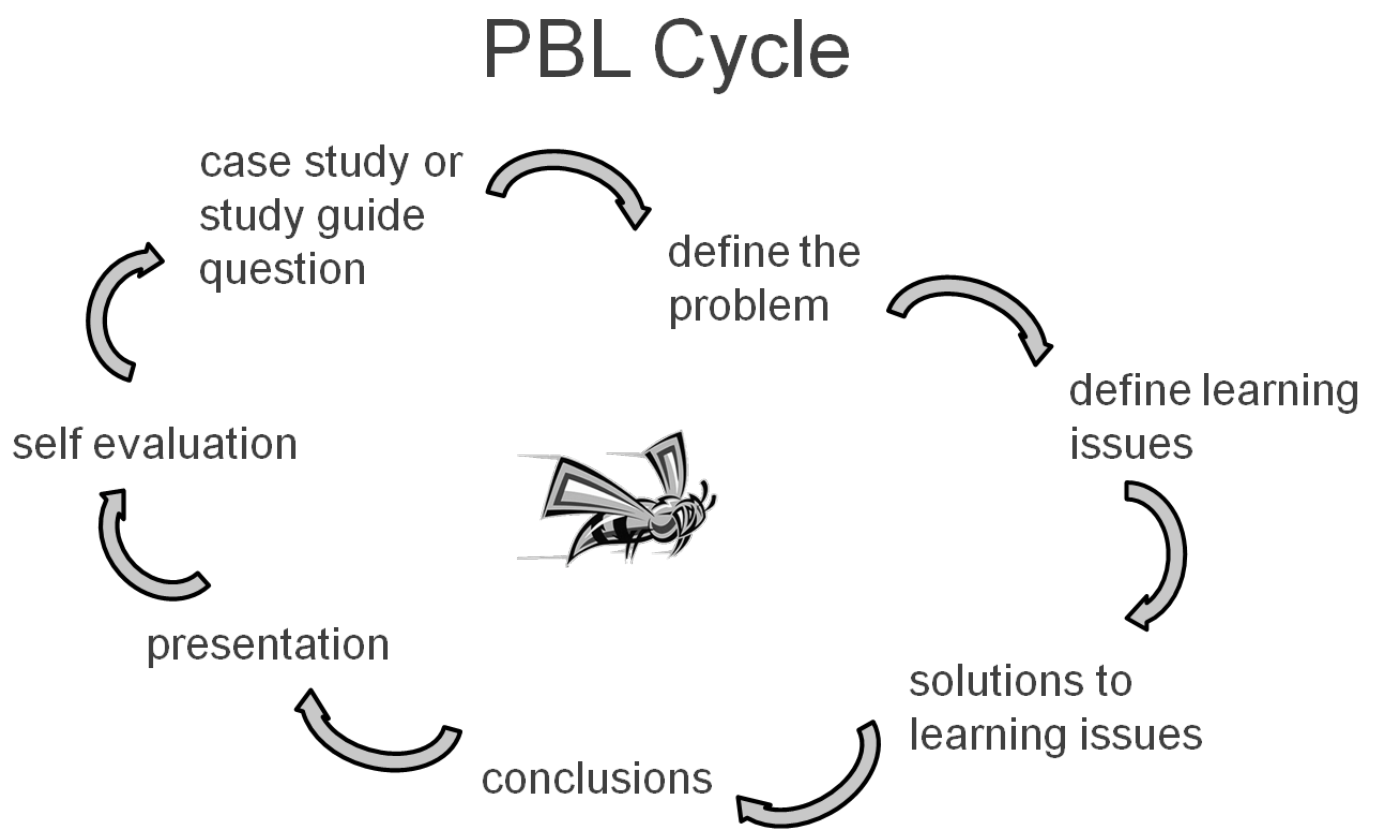

A customized oral communication rubric was used to measure each group's competency during their presentation (Table 1). This rubric was designed using the constraint that oral communication competency was demonstrable across four criteria as follows: delivery, use of terminology, supporting material, and audience engagement. The delivery criterion evaluated each group member's use of nonverbal communication cues and techniques (e.g., hand gestures, bodily posture, eye contact, vocal expressiveness) to coherently communicate messages to the audience. The terminology criterion measured the extent to which clinical terminology appropriate to the course content was used, in addition to providing layman explanations to enhance the audience's comprehension of the topic. The supporting material criterion assessed the use of demonstrations, illustrations, and models to help explain details in the presentation. The audience engagement criterion measured the ability to demonstrate use of various presentation techniques (e.g., demonstrating therapeutic exercises, posing thought-provoking questions to the audience, using humor or games to elicit positive responses from the audience) to interact with and engage the audience. Collectively, these four criteria were selected to provide direct and observable evidence to be used for a blinded rating of oral communication competency during digital recordings of student group presentations. 
Table 1. Customized oral communication rubric used to evaluate four criteria elements of this competency.

\begin{tabular}{|c|c|c|c|c|c|c|}
\hline Score & Comments & $\begin{array}{l}\text { Criteria } \\
\text { Element }\end{array}$ & $\begin{array}{c}\text { Perfect } \\
(4 \text { points })\end{array}$ & $\begin{array}{l}\text { Above average } \\
\text { (3 points) }\end{array}$ & $\begin{array}{c}\text { Average } \\
(2 \text { points })\end{array}$ & $\begin{array}{c}\text { Inadequate } \\
\text { (0 points) }\end{array}$ \\
\hline$/ 4$ & & $\begin{array}{l}\text { Student group } \\
\text { demonstrates } \\
\text { presentation } \\
\text { delivery techniques } \\
\text { (e.g., posture, hand } \\
\text { gesture, eye } \\
\text { contact, and vocal } \\
\text { expressiveness). }\end{array}$ & $\begin{array}{l}\text { All group members } \\
\text { demonstrate } \\
\text { professional } \\
\text { delivery techniques } \\
\text { that enhance the } \\
\text { cohesion of the } \\
\text { presentation } \\
\text { including: } \\
\text { confident tone } \\
\text { voice and } \\
\text { projection, } \\
\text { purposeful pace } \\
\text { and enthusiasm. }\end{array}$ & $\begin{array}{l}\text { All group members } \\
\text { demonstrate } \\
\text { professional delivery } \\
\text { techniques, yet } \\
\text { delivery techniques } \\
\text { may be ridged or } \\
\text { unnatural which } \\
\text { compromised the } \\
\text { cohesion of the } \\
\text { presentation. }\end{array}$ & $\begin{array}{l}\text { A majority of group } \\
\text { members demonstrate } \\
\text { some professional } \\
\text { delivery techniques } \\
\text { yet inconsistencies } \\
\text { compromise the } \\
\text { cohesion of the } \\
\text { presentation. }\end{array}$ & $\begin{array}{l}\text { Delivery techniques } \\
\text { of all group members } \\
\text { detract from the } \\
\text { cohesion of the } \\
\text { presentation. }\end{array}$ \\
\hline$/ 4$ & & $\begin{array}{l}\text { Student group } \\
\text { demonstrates use } \\
\text { of language by } \\
\text { using clinical } \\
\text { terminology which } \\
\text { avoids slang and } \\
\text { layman's terms. }\end{array}$ & $\begin{array}{l}\text { All group members } \\
\text { demonstrate } \\
\text { authentic use } \\
\text { clinical term } \\
\text { authentic use term } \\
\text { without slang and } \\
\text { layman's terms. }\end{array}$ & $\begin{array}{l}\text { All group members } \\
\text { demonstrate authentic } \\
\text { use clinical } \\
\text { terminology } \\
\text { throughout most of the } \\
\text { presentation, with } \\
\text { minimal slang and } \\
\text { layman's terms. }\end{array}$ & $\begin{array}{l}\text { A majority of group } \\
\text { members attempt } \\
\text { fluency of } \\
\text { terminology, yet } \\
\text { elements of layman } \\
\text { terminology exist } \\
\text { throughout the } \\
\text { presentation. }\end{array}$ & $\begin{array}{l}\text { Most group members } \\
\text { do not use clinical } \\
\text { instead use slang and } \\
\text { layman's terms. }\end{array}$ \\
\hline$/ 4$ & & $\begin{array}{l}\text { Student group } \\
\text { demonstrates } \\
\text { interaction with } \\
\text { supporting } \\
\text { material by using } \\
\text { demonstrations, } \\
\text { illustrations, and } \\
\text { models. }\end{array}$ & $\begin{array}{l}\text { All group members } \\
\text { demonstrate } \\
\text { Interaction with } \\
\text { supporting } \\
\text { materials by using } \\
\text { a variety of } \\
\text { demonstrations, } \\
\text { illustrations, } \\
\text { models which } \\
\text { enhances the } \\
\text { credibility of the } \\
\text { presentation. }\end{array}$ & $\begin{array}{l}\text { All group members } \\
\text { demonstrate } \\
\text { Interaction with } \\
\text { supporting materials } \\
\text { by using limited } \\
\text { variety of } \\
\text { demonstrations, } \\
\text { illustrations and } \\
\text { models which } \\
\text { enhances the } \\
\text { credibility of the } \\
\text { presentation. }\end{array}$ & $\begin{array}{l}\text { A majority of group } \\
\text { members attempt } \\
\text { interaction with } \\
\text { supporting materials to } \\
\text { enhance the credibility } \\
\text { of the presentation by } \\
\text { using one of the } \\
\text { following types: } \\
\text { demonstrations, } \\
\text { illustrations or models. }\end{array}$ & $\begin{array}{l}\text { All group members } \\
\text { do not use } \\
\text { supporting materials } \\
\text { which diminishes the } \\
\text { credibility of the } \\
\text { presentation. }\end{array}$ \\
\hline$/ 4$ & & $\begin{array}{l}\text { All group members } \\
\text { consistently } \\
\text { demonstrate } \\
\text { techniques to } \\
\text { engage the } \\
\text { audience and } \\
\text { enhance the quality } \\
\text { of the presentation: } \\
\text { provocative } \\
\text { questions using } \\
\text { humor and other } \\
\text { means to elicit a } \\
\text { response from the } \\
\text { audience. }\end{array}$ & $\begin{array}{l}\text { All group members } \\
\text { consistently } \\
\text { demonstrate } \\
\text { techniques to } \\
\text { engage the } \\
\text { audience and } \\
\text { enhance the quality } \\
\text { of the presentation: } \\
\text { provocative } \\
\text { questions using } \\
\text { humor and other } \\
\text { means to elicit a } \\
\text { response from the } \\
\text { audience. }\end{array}$ & $\begin{array}{l}\text { All group members } \\
\text { demonstrate } \\
\text { techniques to engage } \\
\text { the audience by using } \\
\text { a limited variety of the } \\
\text { following that may not } \\
\text { necessarily enhance } \\
\text { the quality of the } \\
\text { presentation: posing } \\
\text { provocative questions, } \\
\text { using humor, and } \\
\text { using other means to } \\
\text { elicit a response from } \\
\text { the audience. }\end{array}$ & $\begin{array}{l}\text { A majority of the } \\
\text { group members use } \\
\text { either some or only } \\
\text { one of the following } \\
\text { audience engagement } \\
\text { techniques, but they } \\
\text { may be used } \\
\text { inappropriately or } \\
\text { ineffectively: posing } \\
\text { provocative questions, } \\
\text { using humor, and/or } \\
\text { using other means to } \\
\text { elicit a response from } \\
\text { the audience. }\end{array}$ & $\begin{array}{l}\text { Most or all group } \\
\text { members do not use } \\
\text { audience } \\
\text { engagement } \\
\text { techniques. }\end{array}$ \\
\hline
\end{tabular}

Oral communication was assessed at two periods during a 15-week semester: at week 3 (P1) and at week 12 (P2). At each period, student case report presentations were digitally recorded and uploaded to a server for a future rating using the customized rubric. In between data collections, students engaged in the PBL operations of oral presentations, peer review, and formative assessment using the same rubric (Figure 2). Prior to oral communication rating, the study raters (C.A.G; T.K.H; L.A.V) conducted pilot sessions using the rubric to improve the agreement of the instrument. Each group's oral presentations were evaluated independently by two raters who were blinded to period. Pearson product moments were used to assess the agreement of the raters' score for each period. A dependent t-test was used to assess changes to oral communication competency across period; $\alpha<.05$. 
Figure 2. Students engaged in peer-review formative assessment of oral communication following group presentations during laboratory session. Each student group was responsible to assess another group based on the customized oral communication rubric (Table 1).

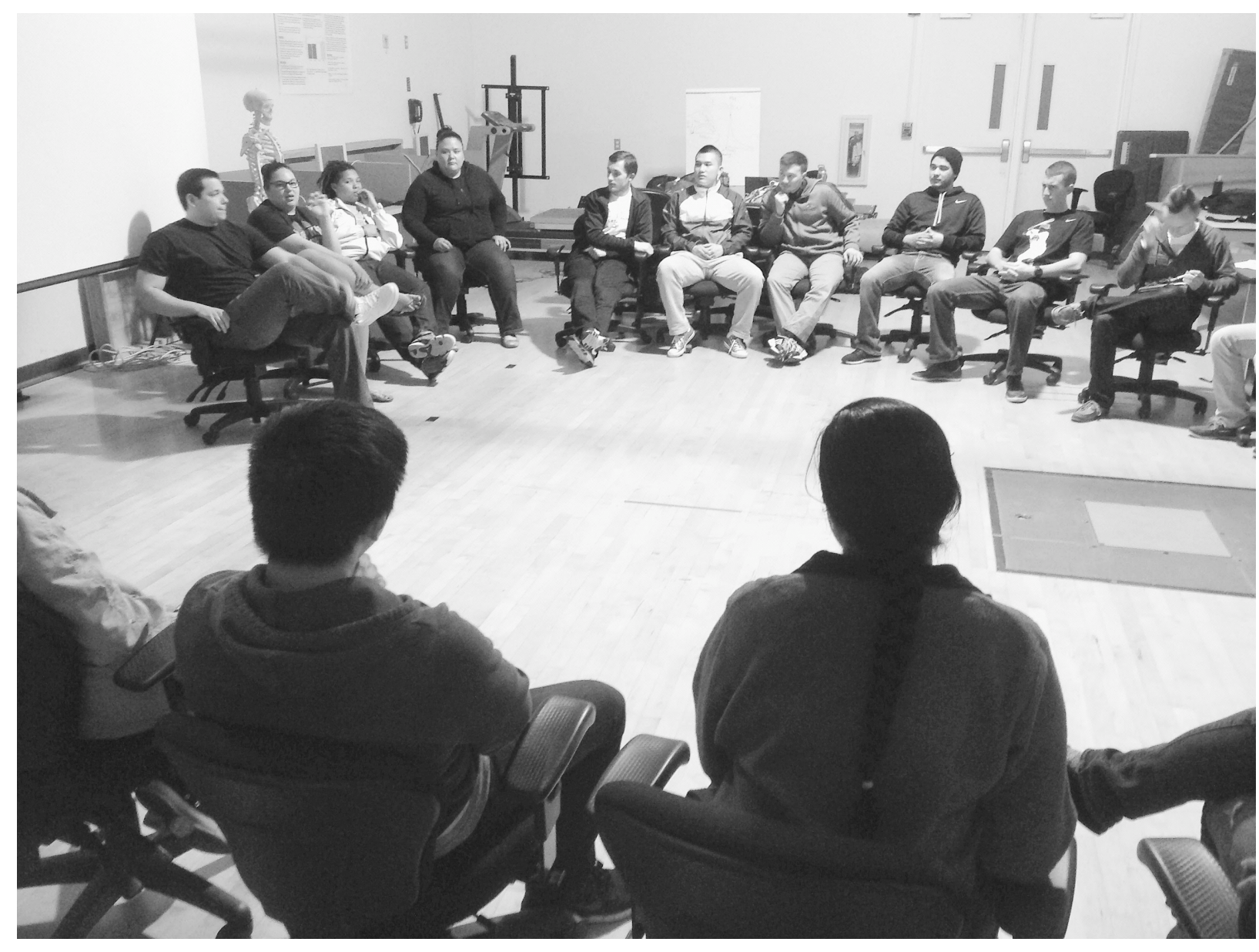

\section{RESULTS}

Thirty-two groups totaling one hundred percent of the students began the study as part of their course work. However, three groups did not complete the semester together and their data were removed from future analysis. These groups disbanded via a mechanism by which groups were able to anonymously rate their colleagues' weekly contribution. These ratings were used to remove malingering students who did not respond to feedback. Malingering students then completed the weekly laboratory case reports as individuals.

The inter-rater reliability of the oral communication rating was shown to be significant and of moderate strength at both P1 $(\mathrm{r}=.629, p<.0001)$ and P2 $(\mathrm{r}=.518, p=.004)$; thus, the two evaluator scores were averaged at both time points. A significant increase across time was found for the mean group oral communication rating $(\mathrm{t}=-3.20, p=$ $.003)$ between P1 $(9.40 \pm 2.70)$ and P2 (10.66 \pm 2.23 ; Figure 3$)$. 
Figure 3. Mean oral communication rating across a 15-week semester, scored at two time points: P1 (week 3) and P2 (week 12).

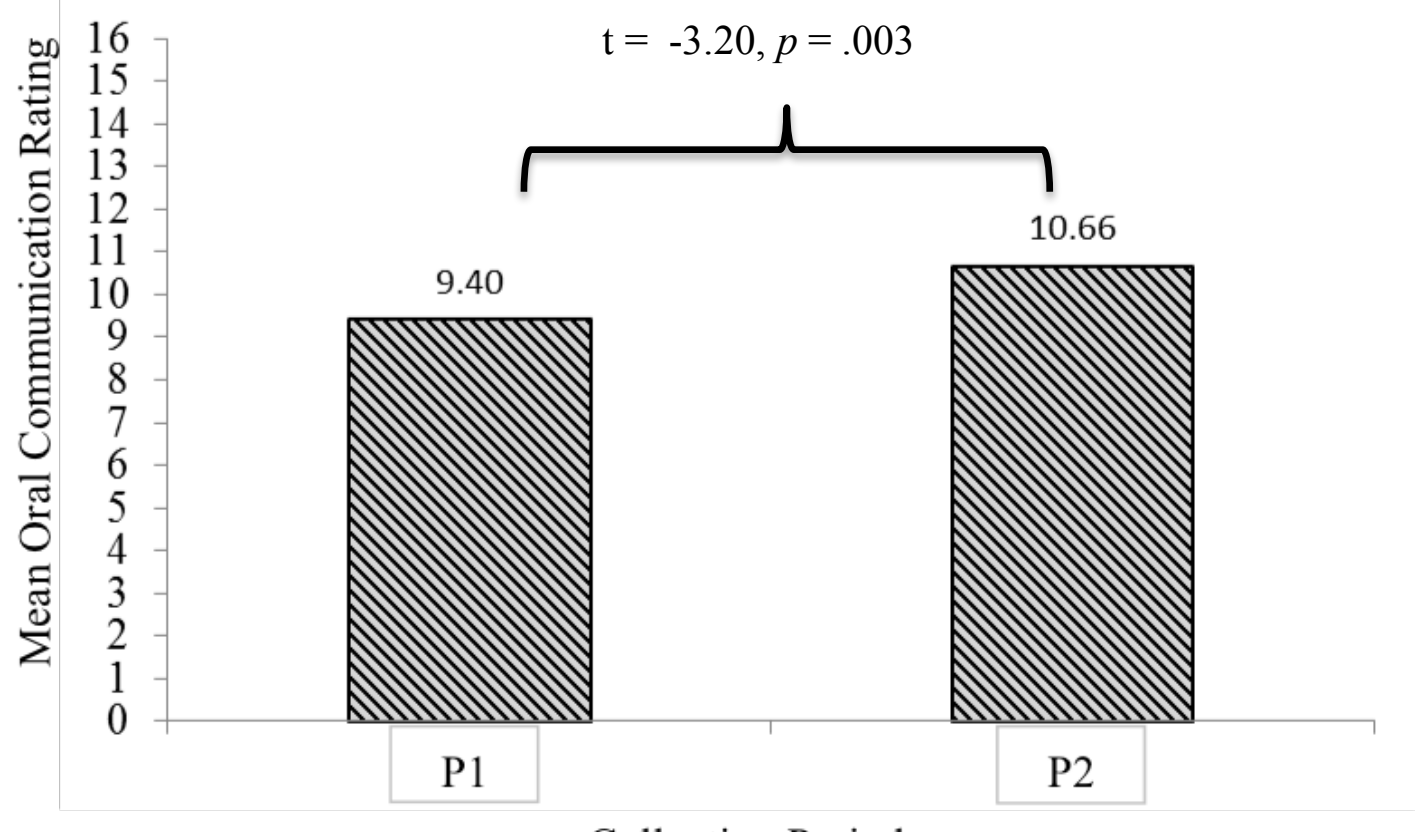

\section{Collection Period}

\section{DISCUSSION}

Within the context described by the competency-based curricula and the collaborative learning models, we believe that optimal undergraduate education is more than the acquisition of content knowledge and G.P.A., but also prepares students to manage ambiguous real world problems via a developing set of professional competencies. Therefore, the purpose of this study was to quantify undergraduate student gains in the professional competency of oral communication for a Problem Based Learning (PBL) Kinesiology course. Our results indicate that students engaged in a PBL Kinesiology course demonstrated significant gains in oral communication competency across a 15-week semester.

The students' oral communication competency gains were likely the result of weekly exposure to the PBL operations of oral presentations and peer-review formative assessments. However, previous studies report equivocal results for the effect of PBL on oral communication competency gains. When studying the effect of PBL on oral communication for Geography undergraduates, students self-reported no gain for their perceived oral communication competency, as students relied on group members with already-established oral communication skills during group presentations (Spronken-Smith, 2005). Differences between this report and our findings may be the result of methodological differences.

Polanco et al., (2004) reported the effect of PBL on oral communication for undergraduate Engineering students. Students displayed significantly greater oral communication compared to their peers in traditional lecture. The author proposed the idea that undergraduate students graduate from their programs with professional competencies that are transferrable across various domains of their career. This notion is consistent with our goal to add an enduring value to the undergraduate education by developing the professional competencies of: problem solving, evidence-based practice, critical thinking and oral communication.

While the undergraduate students reported here demonstrated significant oral communication competency gains across the 15 week semester, the mean scores indicate that the students' ability has room for improvement and likely lies on the novice end of the spectrum of ability. This finding is consistent with the self-report data for PBL Chemistry students who reported that oral communication was developed less than problem solving, time 
management and working in a team (Williams \& Handa, 2016). Not only is oral communication a difficult skill to acquire, but students' also self-report challenges during their initial experience of PBL including: concern about uncertainty and confusion; as well as frustration related to lack of guidance (Yuan et al., 2011; Al-Kloub et al., 2014). Thus, oral communication appears to be a difficult skill to acquire across a semester of collaborative learning which may offer socio-emotional experiences that challenge a student's motivation.

Understanding the underpinning motivational orientation which leads to competency development in collaborative learning may increase the magnitude of these gains. Student goal profiles have a complex multiplicity of direction and orientation. In the Wosnitza and Volet (2012) study, performance goals did not discriminate as well as learning and well-being goals. This finding supports the idea that a student's perception of a positive classroom climate is conducive to effective learning and competency development. The authors suggested that the small groups of collaborative learners be constructed with the students' goal orientations in mind in order to optimize the motivational benefits previously described for collaborative learning (Blumenfeld et al., 2006).

The need to describe the individual and social aspects of motivation for collaborative learning is based on the challenges which PBL students will encounter in their group work including: differences in their goal orientations, cultural backgrounds, and level of content mastery. The extent to which groups can be formed a priori, with heterogeneous pairings of students with respect to these considerations, the greater the peer-to-peer motivation can be optimized for PBL (Wosnitza \& Volet, 2012) and thus greater competency gains may be achieved across the semester.

Nonaka's model of knowledge creation adds complexity to the understanding of goal orientation by including the following sequence of phases of learning: socialization, externalization, combination, and internalization (Nonaka, Konno \& Toyama, 2001). These phases of knowledge creation were present in the PBL Kinesiology course studied here. The socialization phase occurred first during face-to-face exchange of ideas in the laboratory setting (Figure 4). This was then followed by the externalization phase occurring within the on-line collaborative work environment of Google Docs. Here, the development of the case report via the problem solving cycle (Figure 1) was formalized as students articulated and edited their initial ideas from their laboratory meeting. The combination phase of Nonaka's Model occurred with the integration of evidence from peer-reviewed sources into their existing case report. Thus, based on Nonaka's model of the various phases of knowledge creation, one can imagine a student requiring different motive drives to address the various levels of goal direction found in the collaborative learning environment. Future work may assess student goal orientation following the separate phases of knowledge creation seen during the face-to-face and the on-line learning environments. 
Figure 4. Students engaged in the socialization phase of knowledge creation during face-to-face exchange of ideas during laboratory session. Students chose an open ended clinical problem from a menu of options and then developed division of labor and an initial strategy to accomplish the problem solving technique described in Figure 1.

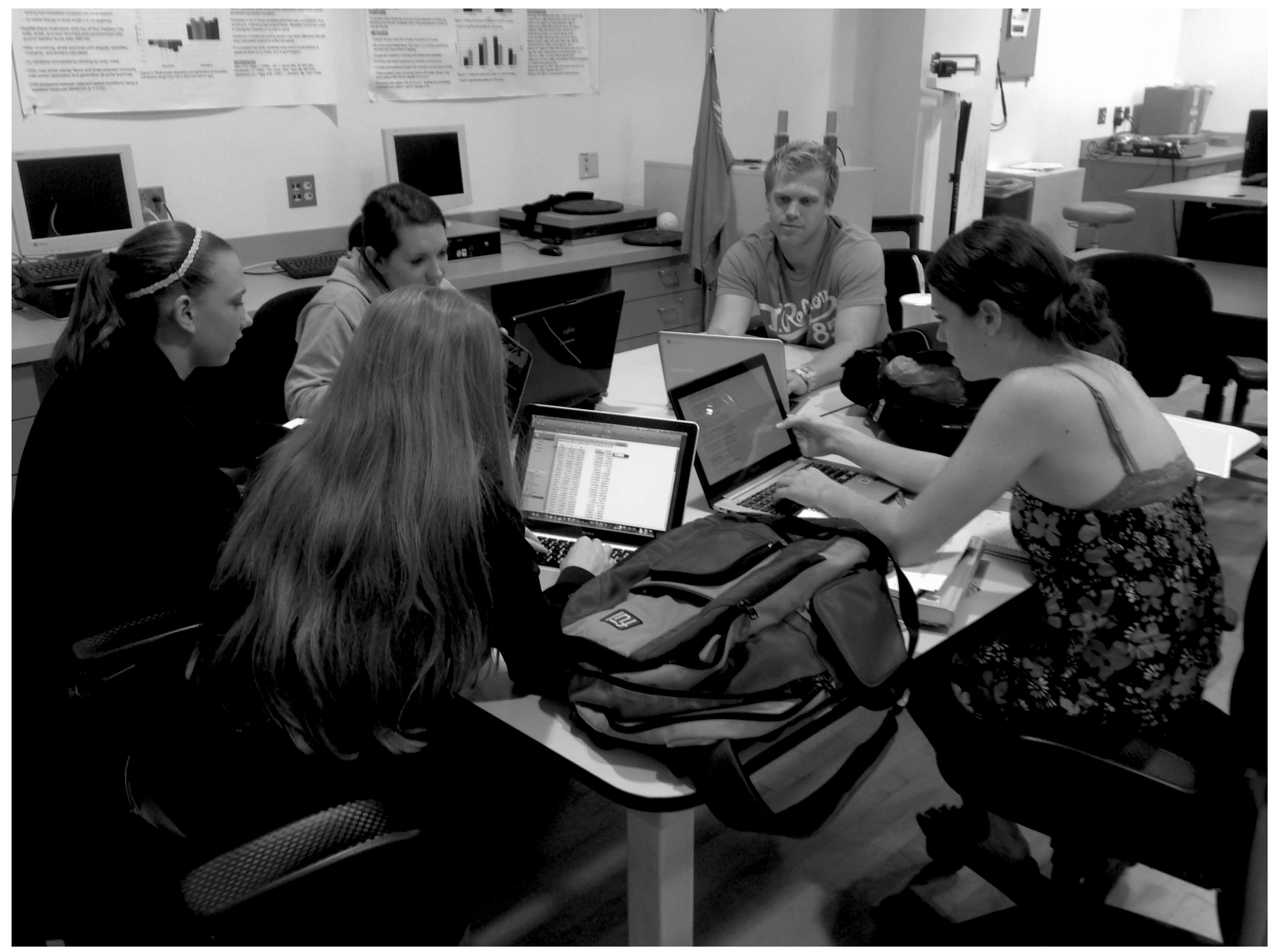

Although PBL students showed significant gains in oral communication competency, the need to engage students in a progression of competence development across a collaborative learning curriculum becomes important to avoid a receding of the ability prior to graduation. Thus, the onus lies on the educator to design learning environments which progressively incorporate prior learning and competency development via curricula which emphasize peerreview formative assessments rather than summative assessments (Frank, 2010). This becomes especially important as the understanding of health care competency is redefined from content knowledge mastery to the ability to collaboratively manage ambiguous real world problems while communicating remotely (Epstein \& Hundert, 2002). Thus, while we have made a commitment to developing problem based learning environments as well as a novel assessment tool of oral communication competency; without a continuum of competency development across a curriculum, it is unknown if these gains will persist following graduation.

\section{CONCLUSION}

The results of this study indicate that the Problem Based Learning (PBL) environment promotes undergraduate students' development of oral communication competency. Future work is required to elucidate the role that student motivation plays in the development of the professional competencies. Such information could be used to organize student groups to optimize competency development. Areas of interest would be the social component of motivation as well as the changes of student goal orientation across the various phases of knowledge creation. 


\section{AUTHOR BIOGRAPHIES}

David S. Mandeville, received the Ph.D. in Biomechanics from University of Oregon. Recently, he as explored collaborative teaching methods for both Kinesiology and Biomechanics curriculum.

Tiffanie K. Ho, M.A., MBA, is an institutional researcher at a private institution. She has a strong interest in student learning outcomes' assessment research.

Lindy A. Valdez, Ed. D., is a professor in the Department of Kinesiology and Health Science at California State University, Sacramento. He is an international scholar in pedagogy and attitudes in Physical Activity.

\section{ACKNOWLEDGEMENTS}

The authors wish to thank: Caroline A. Gibbs for her contribution to the development of the oral communication rubric; the Academic Technology and Creative Services Unit at CSUS for their contribution to the recording of student presentations; Mark Stoner, Ph.D. and Kimo Ah Yun, Ph.D. for their inspiration and guidance provided through the Center for Teaching and Learning, CSUS.

\section{REFERENCES}

Albanese MA, Mejicano G, Mullan P, Kokotailo P, Gruppen L. (2008). Defining characteristics of educational ceompetencies. Med Educ, 42(3), 248-255.

Albanese, M. A., \& Mitchell, S. (1993). Problem-based learning: A review of literature on its outcomes and implementation issues." Academic Medicine, 68(1), 52-81.

Al-Kloub, M. I., Salameh, T. N., \& Froelicher, E. S. (2014). Nursing students evaluation of problem based learning and the impact of culture on the learning process and outcomes: A pilot project. Nurse education in practice, 14(2), 142-147.

Biggs, J. (1999). What the student does: Teaching for enhanced learning. Higher Education Research \& Development, 18(1), 5775.

Blumenfeld, P. C., Kempler, T. M., \& Krajcik, J. S. (2006). Motivation and cognitive engagement in learning environments. Cambridge University Press.

Dods, R. F. (1997). An action research study of the effectiveness of problem-based learning in promoting the acquisition and retention of knowledge. Journal for the Education of the Gifted, 20(4), 423-37.

Epstein, R. M., \& Hundert, E. M. (2002). Defining and assessing professional competence. Jama, 287(2), $226-235$.

Felder, R. M., \& Brent, R. (2004). The intellectual development of science and engineering students. Part 2: Teaching to promote growth. Journal of Engineering Education, (93)4, 279-291.

Felder, R. M., \& Brent, R. (2005). Understanding student differences. Journal of Engineering Education, 94(1), 57-72.

Frank, J. R., Snell, L. S., Cate, O. T., Holmboe, E. S., Carraccio, C., Swing, S. R., ... \& Harden, R. M. (2010). Competency-based medical education: theory to practice. Medical teacher, 32(8), 638-645.

Gijbels, D., Dochy, F., Van den Bossche, P., \& Segers, M. (2005). Effects of problem-based learning: A meta-analysis from the angle of assessment. Review of Educational Research, 75(1), 27-61.

Mandeville, D. S., \& Stoner, M. R. (2015). Assessing the effect of problem-based learning on undergraduate student learning in biomechanics. Journal of College Science Teaching, 45, 66-75.

Nonaka, L., Takeuchi, H., \& Umemoto, K. (1996). A theory of organizational knowledge creation. International Journal of Technology Management, 11(7-8), 833-845.

Nonaka, I., Konno, N., \& Toyama, R. (2001). Emergence of "ba": A conceptual framework for the continuous and selftranscending process of knowledge creation. In I. Nonaka \& T. Nishiguchi (Eds.), Knowledge emergence: Social, technical, and evolutionary dimensions of knowledge creation (pp. 13-29). Oxford University Press.

Norman, G. R., \& Schmidt, H. G. (1992). The psychological basis of problem-based learning: A review of the evidence. Academic Medicine, 67(9), 557-65.

Polanco, B., Rodrigo, P. C., \& Delgado, F. (2004). Effects of a problem-based learning program on engineering students' academic achievements in a Mexican university 1. Innovations in Education and Teaching International, 41(2), 145155.

Powell, K. C., \& Kalina, C. J. (2009). Cognitive and social constructivism: Developing tools for an effective classroom. Education, 130(2), 241.

Prince, M. J., \& Felder, R. M. (2006). Inductive teaching and learning methods: Definitions, comparisons, and research bases. Journal of Engineering Education, 95(2), 123-138.

Spronken-Smith, R. (2005). Implementing a problem-based learning approach for teaching research methods in geography. Journal of Geography in Higher Education, 29(2), 203-221. 
Vernon, D. T., \& Blake, R. L. (1993). Does problem-based learning work? A meta-analysis of evaluative research. Academic Medicine, 68(7), 550-63.

Vygotsky, L. S. (1962). Thought and language. Cambridge, Massachusetts: MIT press. (Original work published 1934)

Williams, D. P., \& Handa, S. (2016). Chemistry Student Perceptions of Transferable \& Workplace Skills Development. New Directions in the Teaching of Physical Sciences, (11).

Wosnitza, M., \& Volet, S. (2012). Group heterogeneity and homogeneity in personal content goals for a group learning activity: Impact on individual appraisals. Applied Psychology, 61(4), 585-604.

Yuan, H. B., Williams, B. A., Yin, L., Liu, M., Fang, J. B., \& Pang, D. (2011). Nursing students' views on the effectiveness of problem-based learning. Nurse Education Today, 31(6), 577-581. 